Many of the earliest business and administrative letters written in English followed a set of rules called the ars dictaminis, a formal and complex model that prescribed a certain writing style and organization. The necessary pattern of organization was the following: address, salutation, notification, exposition, disposition, valediction, and attestation and date. The dictamen almost completely disappears in the sixteenth century. Did the dictamen disappear suddenly? If so, why? In this paper, I argue that the dictamen disappeared slowly by attrition over the hundred years previous, and further, that it was never universal, as previous scholars have argued. The evidence for the claim that the dictamen was widely used and suddenly disappeared consists mostly of Chancery and government documents. When we take into account the mass of business documents involving ordinary business people, including the largest surviving collection of business documents in English before 1500, the Cely papers, we see that by the late fifteer.h century, ordinary business people were not following the dictamen's conventions.

\title{
Business Writing in History: What Caused the Dictamen's Demise?
}

\author{
Jane Thomas \\ University of Michigan, Ann Arbor
}

Forms and models have always been a basic component of business communication. How we fit our language to various format choices has an impact on message effectiveness, which may be why business writers instinctively stretch and often ignore accepted rules and guidelines for business writing. Reviewing the origins of our present business writing practices can help us understand why we do what we do and why our attempts to fit substance to form are often frustrating and ineffective. In "Studying the History of Business Communication," Locker, Miller, Richardson, Tebeaux, and Yates (1996) discuss the value of historical research: "Understanding the historical, political, social, and material context in which earlier documents were created also helps us be more aware of the web of influences and constraints that affect business communication today and thus helps us to be better able to assess, and if need be, work to change them" (p. 123).

The medieval business documents studied in English thus far follow the set of rules and codes termed the ars dictaminis, or art of letter writing (Richardson, 1984, 1985). In the Renaissance, this formula disappears. Why and exactly when did this apparently much-used formula fall out of fashion?

Previous studies of business and administrative documents have focused on the legal discourse of the Chancery court (Burchfield, 1985; Görlach, 1991; Clanchy, 1979; McIntosh, Samuels, \& Benskin, 1986). Studies of literacy in England (Cressy, 1975; 1980) have enlarged our picture of how ordinary men and women communicated just after the medieval period. Davis' work on the Paston papers (c. 1420-1520/1971) as well as 
early editions of the Plumpton (1461-1552/Stapleton, 1839) and Stonor (1420-1483/Kingsford, 1919) correspondence have contributed primary data for study. Other materials from the medieval period now in print include the collection of royal writs and letters and guild documents of London English from 1384 to 1425 (Chambers \& Daunt, 1967).

The most important work on Chancery English-and, by extension, on business writing in the late medieval period-has been done by Fisher (1977), Fisher, Richardson, and Fisher (1984), and Richardson (1980, 1984, 1985, 1997). Both Richardson and Fisher suggest that the dictamen was the base for all business writing in the medieval period and that it was "universally accepted for public and private correspondence" (Richardson, 1997, p. 136). This conclusion regarding business writing is based on a study of important primary materials, such as the Paston papers and the mass of Chancery documents in the Public Record Office in London. However, I will argue in this paper that the dictamen was not universally accepted by business writers of English and that it did not suddenly disappear in the English Renaissance. Instead, I claim, the old formulas for letter writing were gradually discarded by business people in the hundred or more years prior to 1500 . My support for these conclusions emerges from the language of the Cely letters and papers, language that, except for my dissertation (Thomas, 1994), has not been studied closely and that provides evidence for reconsidering some of our established views on the development of business writing.

The Cely papers are particularly appropriate for a historical study of business writing for three reasons. First, the Celys were a London family, and although they owned property in Essex, their primary residence was in London, and their business affairs were concentrated there. In contrast, the Pastons, Plumptons, and Stonors ran their affairs from their country estates. London was England's business center; London English fed into Chancery English and into what later became standard English (Fisher, 1977). Second, the Celys are firmly based in the middle class. They were never part of the aristocracy or gentry during the span of the letters or later, although they achieved significant economic success and cultivated friends and associates among the aristocracy. They are a clear example the merchant class, even if we can't assume they are representative. Finally, the Cely letters are part of the commercial English that developed against the background of foreign trade. They constitute the largest surviving collection of merchant papers in England before 1500 (Hanham, 1975, p. vii).

The limitations of conclusions based on the Cely papers are obvious: The papers cover only a short period, from 1472-1488, and the collection is smaller than many others of the period. These papers consist of two volumes of letters (Ancient Correspondence [S.C.1] Vols. 53 and 59) and nine files of accounts and memoranda (Chancery Miscellanea [c.47] 
Bundle 37, Files 10-16, 20, 21). There are two additional letters in S.C.1 Vols. 60 and 73. Altogether 247 letters exist (edited and published by Hanham in 1975). More than 400 additional notes, memoranda, and other documents in the Public Record Office have never been published. Even though they cover a short period, the papers offer a clear snapshot of English business writing in the late medieval period. These papers offer surprising insights and are worth considering when studying the development of business writing.

\section{Background}

The Celys were a family of English wool merchants in the latter half of the fifteenth century. Richard Cely Senior seems to have begun the business simply by traveling to the countryside to buy wool from sheep farmers and then selling it in London or shipping it to Calais as fells, or undressed hides. From Calais, the Celys' representative would travel to the great medieval marts with the fells, which had been stored in Calais in the interim. Richard Senior had three sons who shared the business with him and who carried it on after his death. They were all members of the wool guild, the Merchant of the Staple, wool being a "staple" product of England during the medieval period.

The Celys appear to have been successful economically, although during this period, the wool trade was decreasing. To determine how successful a merchant was, it is necessary to consider not only the value of the goods involved but also the volume of goods moved and the margins of profit generated (Dyer, 1989, p. 29). One additional measure of success for merchants was whether or not they participated in loans to the government. By the Celys' period, it was common for the Crown to demand personal "loans" of fixed sums from individual merchants. The Celys were successful enough to have had the dubious honor of being a part of this group, with evidence of loans and contributions recorded on several occasions (Hanham, 1985, p. 236). Although it is difficult to know exactly what the Celys' annual income was, and the income fluctuated from year to year depending on political and economic conditions, it is possible to estimate their relative wealth based on their volume of trade and the general margin of profit in the wool trade. Hanham suggests that in a typical year after Richard Senior's death, Richard Junior and George would each have enjoyed an income of more than $\$ 100$, an income that places them in the same category of an aristocrat owning land worth more than $£ 2000$ (1985, pp. $420-421$ ).

The Cely papers have survived for two reasons: First, the fifteenth century was quite litigious, and second, the youngest son George had a habit of never throwing anything away. In 1490, Richard Junior sued the widow of his brother George for debts accrued during the thirteen-year period that the two had been trading partners. In the subsequent litigation, a 
great number of documents were delivered to the Court of Chancery. When the sifting through was completed, only a few business ledgers were returned to the family. The rest of the material lay in storage in the Tower of London until the Public Record Office was established and the documents were moved there and catalogued. Unfortunately, no record survives regarding the outcome of the lawsuit.

Most of the letters and other documents that make up the Cely papers were not drafts or copies but were actually sent (Thomas, 1994, p. 8). As was usual in that period, they were delivered by friends or servants, or sometimes other people's servants, as evidenced in File 13 folio 26 where George sends a piece of face armor to Calais with "Alan Redeman's servant" and pays him 5-1/2d for his trouble. The letters sent from one Cely to another, of course, were turned over to Chancery during the litigation, as well as the business letters from other business associates to the Celys. More than forty writers are represented in the Cely letters, and it is not possible to know whether or not the letters are all autograph, that is, written in the author's hand rather than by a scribe. However, a reading of the original letters and papers makes it clear that most of the letters written by Richard Senior and his three sons are in their own hands. Hanham suggests that most of the other letters are also autograph, as well as one of the two letters written by women (1985, p. 315). Many of the currently unpublished papers still in the Public Record Office in London are George's notes and memoranda, including lists of purchases and his own business accounts. Most of this material is in George's slightly rounded and uneven hand. Although most of the memoranda are "things to be remembered" and written as the writer's notes to himselfin this case, George Cely-three of the documents are internal notes to someone else, all three written by George Cely (Ch. Misc. C. 47/37/12 f.6; S.C.I 53/55; S.C.I 53/65).

\section{Methodology}

Information in this paper is based on research done for my 1994 University of Michigan English dissertation, The Language of the Celys. After reading Hanham's edition of the letters, I spent several weeks in the Public Record Office in London reading the originals of the printed letters as well as the unpublished documents. With microfilm copies of all this material, I reviewed each document using historical methods developed by McIntosh, Samuels, and Benskin in the Linguistic Atlas (LALME, 1986) as well as research by other historians and linguists, such as Görlach, Fisher, and Richardson.

\section{Writing Practices of the Celys}

It is evident from the letters that Richard Cely Senior and his three sons could read and write English as could most of their recipients. How- 
ever, we do not know the extent of their education and how they acquired it. During the fifteenth century, a person was thought to be literate if he or she could read and write Latin. This definition of literacy ignored the massive amount of business, both social and economic, that was conducted in the vernacular.

Oportunities for education were abundant in the fifteenth century, especially in London. To do business at all, merchants had to be able to read and do accounts, and the merchant class as a whole wanted its sons to enjoy the benefits of learning. Legacies left to sons often included money for schooling, with amounts ranging from that which would only cover learning to read and write to that which would support a son until he was twenty (Thrupp, 1992, p. 160). Formal business studies, which included French, the dictamen, rhetoric, accounting, and often common law, were centered in Oxford from the early thirteenth century until the latter half of the fifteenth when these subjects were taken over by other institutions, such as the Inns of Court (Orme, 1973, p. 78).

It would appear from the Cely letters and files that the Celys' formal education was fairly rudimentary. There is no direct evidence that they could write Latin since they did not use any Latin phrases or words except in the most elementary way (e.g., referring to the year as anno 1479). They did not write in French, either. George probably communicated to some extent in French and perhaps Flemish in order to conduct business at the medieval marts of Europe. Their letters do not follow the conventions of the dictamen except in a superficial way.

\section{Dictamen}

The art of letter writing (ars dictaminis) in the medieval period was based on rhetorical principles developed in ancient Greek and Rome (Hildebrandt, 1985, p. 53). Conventions of the dictamen included both form and style, the form consisting of various sections of the message organized in a particular way and style referring to language used in an appropriate manner for the message as well as word choices that signaled the reader to expect a change of idea (Hildebrandt, 1985, p. 60; Richardson, 1985 , p. 28).

Although the content would change depending on the purpose of the letter, generally the organization and style would follow this pattern (Richardson, 1985, p. 28):

1. Address: formulaic and polite, e.g., "right worshipful sir," "well beloved brother," "worthy and worshipful father."

2. Salutation: e.g., "I greet you well," "I recommend me unto you," etc.

3. Notification: e.g., "and let you know that. ..," "and please you to wit that. .."

4. Exposition: further information about and explanation of the subject. 
5. Disposition: e.g., "whereupon," "wherefore," "whereof"; a request or demand.

6. Valediction: e.g., "God have you in his keeping. . ." etc.

7. Attestation and Date: "written at ..." plus the date, often written as the year of the king's reign.

Richardson expands this definition of dictamen rules in his discussion of "Women, Commerce, and Rhetoric in Medieval England." A second type of dictamen, he states, used more for family letters was a "looser version" than that found in the government documents of the period (1997, pp. 136-137). Richardson also shows that the dictamen conventions guided not only the overall organization of letters but also the information included in the body, with a division between the first part consisting of the background and/or a reminder of the context and the second part consisting of what the writer wanted done (1985, p. 28). Overall, the Cely letters approach the "looser" organization as described by Richardson, but at times they omit whole sections of the dictamen and do not in any way show the internal structure that Chancery documents illustrate.

\section{Content of the Cely Papers}

The Cely papers (1472-1488) cover a period that saw four kings on the English throne, the climax of the Wars of the Roses, its resolution on Bosworth Field, and the beginning of the Tudor dynasty. Commentary on these events in the Cely letters is remarkably absent. Political figures, including the king, are mentioned, but almost always in innocuous contexts, such as in a reference to a loan the Merchants of the Staple (the wool traders' guild) had given the king. Censorship occurred, of course, during some periods, and most people assume that letter writers were careful about what they wrote. Even so, the Pastons left rather clear comments on political events (Davis, 1971).

The Celys, though, rarely mention political events. Except for one letter, which is full of the rumors regarding the disappearance of the young King Edward V, the political references are brief and almost always concern business matters. At the same time, a reading of all their letters and other documents suggests that the writers did not seem to take special care with their words or subject matter. The Celys seem to deal with public concerns only when forced to.

Almost all the letters involve a business issue or problem, although family and personal news was also included. Common topics of the letters include whether or not a shipment of Cely wool arrived safely in Calais, the price received for it, and the successful (or unsuccessful) delivery of it. Also discussed are bills and payments owed to others or that others owed to the Celys, as well as payments required by the king and the often fluctuating exchange rate between London and Calais. Personal news 
could range from the health of a family member to the Cely horses and hounds.

\section{Features of the Cely Letters}

Letters written by the Celys do show evidence of familiarity with the principles of the dictamen, primarily in the beginnings and endings. Of the 108 letters written by Richard Cely Senior and his sons, 77 begin with a polite address and include a salutation:

Welbelouyd brother, I recomaund me herttely to yow. . . .

(Hanham, 1975, letter \#3; S.C.I 53/3; Robert Cely to George Cely, 13 April 1476)

Welbelouyd brother George, I recomend me harttely onto you. . . . (Hanham, 1975, letter \#8; S.C.I 53/204; Richard Cely Junior to George Cely, 28 October 1476)

Ryght whellbelovyd brothyr, I recomeavnde me vnto as lowyngly as I con or may.

(Hanham, 1975, letter \#4; S.C.I 59/17; George Cely to Richard Cely Junior, 27 September 1476)

Letters by other writers in the collection usually also contain the prescribed polite address and salutation, exemplified by the usual address of the careful William Cely (the family's factor in Calais):

Ryght worschyppffull masters, affter all dew recommendacyon I lowly recommend me vnto yowre masterschyppys.

(Hanham, 1975, letter \#182; S.C.I 53/135; William Cely to Richard Junior and George Cely, 13 August 1482)

However, many of the letters deviate from this pattern. Of the 33 letters written by Richard Cely Senior, 31 skip the address and cut right to the salutation, as in the following examples:

I grete the wyll, and I haue resayuyd a letter from the. . .

[I greet thee well, and I have received a letter from thee. . . . ]

(Hanham, 1975, letter \#2; S.C.I 53/2; Richard Cely Senior to Robert Cely, 5 July 1474)

I grete the wyll, and I haue grete marvele that ye wryt not to me. . . [I greet thee well, and I marvel greatly that you have not written to me.] (Hanham, 1975, letter 11; S.C.I 53/197; Richard Cely Senior to George Cely, 26 January 1476/7)

I grete the wyll, and I understand there com no marchauntys to Caleys for to bye woll nor fellys. . . . 
II greet thee well, and I understand no merchants have come to Calais to buy wool or fells. ... .]

(Hanham, 1975, letter \#12; S.C.I 53/7; Richard Cely Senior to George Cely, 23 May 1477)

Sometimes, Richard Senior is in too much of a hurry for any conventional opening:

Item, be the grace of God, I haue schepyt woll and fell at Porte London in my name.

[Item, by the grace of God I have shipped wool and fells at Port London in my name.]

(Hanham, 1975, letter \#104; S.C.I 53/54; Richard Cely Senior to George, 25

September 1480)

Other writers, too, often skip the formalities or include them in abbreviated form, such as the beginning of the letter from the upper-class Sir John Weston to George Cely:

Worshypfull coyssyn, wyth du recomendassyonus premysset, it is so I come to Rome. . . .

[Worshipful cousin (a polite address not implying a blood relationship), with due recommendations stated, it is so that I have come to Rome. . . .] (Hanham, 1975, letter \#129; S.C.I 53/83; Sir John Weston to George Cely, 27 October 1481)

A letter from a business associate to George has an address but no salutation:

Mester Cely, I pray yow let yowr man do so myche ffor me as to go to ... [Mr. Cely, I pray you let your man do so much for me as to go to . . .

(Hanham, 1975, letter \#97; S.C.I 53/128; 19 July 1480)

And finally, the opening of the letter from a disgruntled business associate:

Syr, and yt pless yowr masterschypp . . . thys man has sayd ffor hymselff as whell as he con. I besek ye gew me leffe to say for myselffe.

[Sir, and it please your mastership ... this man has told you his side of the matter. I beseech you to give me leave to speak for myself.]

(Hanham, 1975, letter \#7; S.C.I 53/202; Thomas Miller to George Cely, 1476)

One of the main points to note in the above examples and in almost all the published letters in the Cely collection is the quick turn to the issues of concern in what we would consider a direct organizational pat- 
tern, or putting the main news up front. Having said that, it is important to mention that any real organization in the modern sense does not exist in the Cely letters. The principles of notification, exposition, and disposition are ignored as a pattern of organization, the letters showing a mixture of business and personal news, explanations, and requests in varying organizational patterns or, often, no perceptible pattern. However, new topics generally have a transition word or phrase, such as "Sir," "Item," "And," "And as for." This letter written by Richard Cely Senior demonstrates the way material is handled in most of the Cely collection. Many letters ramble on, covering several topics both business and personal. In the example that follows, the topics move from letters received by the writer to news of the sale of fells, a charge, a payment received, lack of news regarding wool, the price of wool, a neighbor selling his land (which the writer does not want), a reprimand for the recipient's leaving for Calais and for his not writing his wife and for not working hard enough. (I have rendered into modern English the words for the sake of clarity but have left the original punctuation and syntax.)

I greet you well, and I have received a letter from you, written at Calais the 24th day of June, which I well understood, and that you have sold your fells, for which I am well pleased, and I have received a letter from Thomas Kesten and a charge for [smudged in the original] . . . he has sent to me for you a letter of payment from Grace, the mercer, for 40 pound sterling payable the 10th day of September at London, and I understand nothing of receiving wool for there are no good directives from headquarters, neither for sales or otherwise, which must be the reason you are slow in writing. And tell Thomas Kesten that I was at the Kettering feast on the Sunday after St. Peter's Day [July 3], for a matter that I had to do there, and the price of wool is 28 pence a stone, as men tell me. John Raunse can tell you. And as for Will Darlington, he's selling his land at Barton, but I don't want it nor does anyone want to deal with him, and tell this to Whethill [comptroller at Calais] or his men. I write no more, but Jesus keep you. And tell George that I had no word from him about your coming to Calais, and your wife thinks you should have written to her. You forget yourself, what you should do. Sloth is a great thing and does as little good for you as leisure does for good business. Written at London the 5th day of July, in haste. (Hanham, 1975, letter \#2; S.C.I 53/2; Richard Cely Senior to Robert Cely, 5 July 1474)

Most of the Cely correspondence contains the final two sections of the dictamen, the valediction and the attestation, or at least the latter. But these sections are often highly abbreviated. For example, a letter from Richard Cely Junior to his brother George omits a valediction and concludes with "Whryt at London [smudged] day of Nowhembyr." Another letter from Richard Junior to George includes a short valediction: "Jhesu kepe yow. Whritte at London the $v$ day of Nowembyr." Twentyeight of the 
108 Cely letters end with some comment that the writer was in a hurry. Most often these expressions are found in Richard Senior's letters (22 of 33). An example is the letter from Richard Senior to George: "Wryt at London the vj day of Novembor in haste." But even when Richard Senior is not in a hurry, he often omits the formalities, as in this ending to a letter to his wife and sons: "Wryte on Thorysday noe in haste."

In contrast to the Celys' letters, those letters in the collection written by their friends and associates more often include a separate valediction and attestation. For example, the letter written by Sir John Weston, to George Cely condenses the address and salutation ("Worshypfull coyssyn, wyth du recomendassyonus premysset") but includes a full valediction and attestation:

Coyssyn, I pray zow sende me worde of zour welfare and comande me To my fader and zours, and zour moder, and Jhesus keppe zow. At Rome, the xxvij day of Octobre 1481, be zour coyssyn Sir John Weston, Pryor of Sant Johns.

[Hanham, 1975, letter \#129; S.C.I 53/83; Sir John Weston to George Cely, 27 October 1481]

Sir John Weston was Prior of St. Johns, a powerful, semi-military knights' order. Although he had scribes to write important letters for him, this letter is believed to be in his own hand. Sir John was very close to the Celys, $\epsilon$ specially Richard Junior, so he could be less formal in his communications with them. In addition, he wouldn't worry about his English because they were friends and because the Celys were much lower on the social scale. Evidence for the letter's being autograph comes from the informal tone as well as the dialect and other linguistic features. Weston uses a number of old-fashioned forms and some regionalisms. Hanham claims that "no secretary could afford to write as badly as the Prior does" (1975, p. 274).

\section{Discussion}

So when and how did the dictamen die? Not suddenly in the Renaissance, I argue-or at least not in England. Rather the dictamen declined slowly over the hundred years prior to the time when we cease to see it in public documents. Furthermore, I doubt that the dictamen was ever as influential in the writing of ordinary people as most researchers believe. Claims about the universality of the dictamen are based on incomplete data. The data provided by the Cely papers strongly suggest an alternative linguistic reality.

The assumptions of a widespread use of the formal rules of letter-writing rest on the documents that have so far been available to researchers; these are mostly in the Public Record Office with some papers residing in such places as the Guild House Library. Most of these documents do 
illustrate the dictamen conventions, but that is because most of these documents originated in the Chancery itself or in other medieval government documents. To base a conclusion on medieval Chancery records ignores the masses of private merchants' documents, of which the Cely papers are an example. Public Record Office officials told me that thousands of documents from the medieval period have never been catalogued and thus have not been available to researchers (personal conimunication, February 21 and February 28, 1992).

Historical research indicates that business was transacted in England for several hundred years before the Renaissance (Bolton, 1980; Chrimes, 1959; Myers, 1985; Thomson, 1958). Initially, transactions were primarily oral, but from the thirteenth century on, there was an increasing need for documentation. Some of this documentation-in English-exists in the official records and in Chancery court (Thomas, 1994; Fisher et al., 1984; Chambers \& Daunt, 1967). In addition, the number of people doing business in England was fairly substantial. Thrupp estimates there were approximately 1200 merchants in London in 1501-1502, many of whom were dealing with markets on the Continent (1992, p. 51). Further, English merchants increasingly used the vernacular language. Until the midfourteenth century, Latin was the language of official English documents, and French was the language of the courts. In 1362, Parliament enacted a statute requiring court proceedings to be conducted in English (Fisher, 1984 , p. xv). This parliamentary action did not arise from a sudden desire for change but rather from the reality that most people were speaking and writing in English and that knowledge of Latin and French was declining, a fact that the wording of the statute makes clear (Fisher, 1983, p. 54). In view of the historical record regarding business, merchants, and the rise in the use of the vernacular, it would be a mistake to assume a universal use of the dictamen based on Chancery and other government documents.

The documents written by the Celys and their associates suggest that the dictamen may not have been as influential as has been assumed. Although these papers indicate a familiarity with the dictamen rules, writers clearly do not feel obliged to follow them. It is not only the Celys themselves who ignore the dictamen in their letters: The other writers also pay little attention to the formal conventions. Of the 247 letters, only a handful follow the prescribed organization and style. Two of this handful are letters from Richard Cely Senior written by a scribe to people of some importance (Hanham, 1975, letters \#16 and \#17; S.C.I 53/198; to an unknown person at Calais and to the Lieutenant of the Staple, 28, February, 1477/8).

The Pastons, too, deviate from the formal rules, illustrating Richardson's "looser" pattern of the dictamen. However, the Paston letters are personal, discussing affairs of state, judicial courts, and internal family matters. The Celys, in contrast, are writing to suppliers and vendors. 
Therefore they provide stronger evidence that the dictamen was not used for business writing.

Hanham considers the Cely papers representative of the merchant class of the late fifteenth century $(1975, \mathrm{p}$. vii). The fact that these documents comprise the largest surviving collection of merchant papers in England prior to 1500 (Thomas, 1994, p. 2) should encourage researchers to include the rhetoric of the Cely papers' linguistic features in studying business writing of the period. Hanham states, "Linguistically, the collection occupies a special position as a record of the commercial English that had been developing over some four centuries of English involvement in international trade, and as a generally unselfconscious reproduction of the speech and writing habits of middle-class Londoners" (p. viii).

Why did the Celys and their correspondents ignore the dictamen? Were they unaware of the rules or unable to conform? Or did they just not care? The Cely letters suggest that the writers were familiar with at least some aspects, particularly openings and closings and an awareness of when they should be formal and when they could skip the politeness. All the letters show sensitivity to audience relationships or status. For example, all the letters from the Cely sons to their father include a polite address and salutation; all the letters from the father to his sons omit the salutation. All letters to persons of greater social status include extensive addresses and salutations and the flowery language reflecting the dictamen style. The handful of letters showing a sense of notification, exposition, and disposition (although in the "looser" style as defined by Richardson) suggest at the very least an awareness of the conventions.

Whether the Cely writers could have conformed to the dictamen rules is more difficult to assess. Their education, as mentioned earlier, was likely to have been no more than some time spent in an elementary school or lower grammar school (Orme, 1973, pp. 60-79; Thomas, 1994, pp. 4450). Nevertheless, the language used for many of the beginnings and endings of the letters as well as the careful use of the address, salutation, valediction, and attestation in some letters indicates that these writers could be appropriately formal when they chose.

Reading the mass of documents in the Cely collection leaves the reader with an overwhelming sense of the writers as people with personality quirks and public and private needs. These writers can be characterized, in modern terms, as down-to-earth, mostly honest, and very busy trying to make their way in the world. The documents themselves show that the information being communicated did not lend itself to the formal rules of medieval letter-writing and that business was simply too important and too immediate for an individual writer to spend the time and effort needed to observe the formalities. The Cely writers observe the dictamen to some degree in some instances, but they clearly do not consider following the rules necessary to communicate effectively with their audiences. 


\section{Conclusion}

Most language changes do not occur suddenly but rather slowly over many years in the habits of speakers and writers. This is most likely what happened to the formal rules for letter writing. Even if we cannot know for sure, the linguistic data from the Cely papers and the historical evidence regarding business in England in the late fifteenth century suggest that it is a mistake to assume a widespread use of the dictamen except in Chancery and official documents. The Cely papers alone may not be enough to prove that the dictamen did not prevail in private correspondence, but they are sufficient to prove that the use of the dictamen was not universal.

In spite of the questions raised by the Cely letters, the dictamen demonstrates both the power and the limitations of form in communication. In one sense, the dictamen has endured to the present day in our conventions of message openings. Modern letters have an address, which we call a salutation ("Dear Dr. Jones") and often a salutation ("How are you?") Closings often have a valediction ("Take care"), and the date is still usually somewhere on the letter, although perhaps not at the end. These sections of the dictamen appear in the Cely papers as well, suggesting that these parts have endured because they serve a communication need.

However, forms can also limit usage, and when those limitations reach a meaningful level of interference, users will ignore them and develop other ways to communicate their messages. A modern example of how writers bypass forms is discussed in Priscilla Rogers' article "ChoiceBased Writing in Managerial Contexts: The Case of the Dealer Contact Report" (1989). In this instance, automotive representatives who met regularly with dealers were asked to follow a stated order in recording each dealer contact. However, instead of filling out the form, most of the representatives wrote narratives of their dealer visits. Rogers discovered that the needs of the writers, who wanted their managers to know how well they were handling their contacts, were better served by the narratives. Another widespread example of changing the traditional forms of written communication is the development of e-mail. Yates and Orlikowski have shown that message structure often reflects organizational imperatives and is influenced by a web of contextual factors (1992, 1995). Casual observation of e-mail indicates that it is changing everything from openings and closings to mechanics, especially punctuation.

As with many modern rules of communication, the dictamen may have been too prescriptive to be useful to ordinary writers such as the Celys. Those who taught the dictamen informed and were informed by the Chancery clerks, but many who were not part of that elite group ignored the rules, just as they do today.

\section{NOTES}

I would like to express special thanks to the reviewers who gave me feedback on this paper. Their comments and suggestions not only helped me avoid some serious errors but 
also guided me in discovering aspects I had not considered.

Material in this article comes from my dissertation directed by Frances McSparran.

Jane Thomas is the Director of Writing Programs and Lecturer in Communication at

the University of Michigan Business School. Her background is in English medieval language and literature with an emphasis on historical linguistics. Her current research interests include intercultural communication and writing assessment. Send correspondence to her at 701 Tappan, Ann Arbor, Michigan 48109-1234<thomasej@umich.edu>

\section{REFERENCES}

Bolton, J. L. (1980). The medieval English economy 1150-1500. London: Clarendon Press.

Burchfield, R. (1985). From William Caxton to George Washington: 1476-1776. In R. Burchfield (Ed.), The English language (pp. 20-33). Oxford: Oxford University Press.

Cely Papers. (1472-1485). S.C.I. Vols 53, 59, 60, 63. Ancient correspondence. Public Record Office, London.

Cely Papers. (1472-1485). Chancery miscellanea, [C. 47] Bundle 37. Files 10-16, 20, 21. Public Record Office, London.

Chambers, R. W., \& Daunt, M. (Eds.). (1967). A book of London English: 1384-1425. Oxford: Oxford University Press.

Chrimes, S. B. (1959). An introduction to the administrative history of medieval England. (2nd ed.). London: Longman.

Clanchy, M. T. (1979). From memory to written record: England, 1066-1307. Cambridge, MA: Harvard University Press.

Cressy, D. (1975). Education in Tudor England. New York: St. Martin's.

Cressy, D. (1980). Literacy and the social order: Reading and writing in Tudor and Stuart England. New York: Cambridge University Press.

Davis, N. (1971). Paston letters and papers of the $15^{\text {th }}$ century. Oxford: Clarendon.

Dyer, C. (1989). Standards of living in the later Middle Ages. Cambridge: Cambridge University Press.

Fisher, J., Richardson, M., \& Fisher, J. (1984). An anthology of Chancery English. Knoxville: University of Tennessee Press.

Fisher, J. (1977, October). Chancery and the emergence of standard written English in the fifteenth century. Speculum, 52(4), 870-899.

Görlach, M. (1991). Introduction to Early Modern English. Cambridge: Cambridge University Press.

Hanham, A. (1975). The Cely letters, 1472-1488. London: Oxford University Press.

Hanham, A. (1985). The Celys and their world. Cambridge: Cambridge University Press.

Hildebrandt, H. W. (1985). A 16th-century work on communication: precursor of modern business communication. In G. Douglas \& H. Hildebrandt (Eds.), Studies in the history of business writing (pp. 53-67). Urbana, IL: Association for Business Communication.

Kingsford, C. L. (1919). Stonor letters and papers. Royal Historical Society, Camden 3rd Series. 2 Vols.

Locker, K. O., Miller, S. L., Richardson, M., Tebeaux, E., \& Yates, J. (1996, June). Studying the history of business communication. Business Communication Quarterly, 59(2), 109127.

McIntosh, A., Samuels, M. L., \& Benskin, M. (1986). A linguistic atlas of late mediaeval English. Aberdeen: Aberdeen University Press.

Myers, A. R. (1985). Crown, household, and parliament in fifteenth-century England. London: Hambledon Press.

Orme, N. (1973). English schools in the Middle Ages. London: Methuen.

Richardson, M. (1980, Spring). The earliest business letters in English: an overview. The Journal of Business Communication 17(3), 19-31.

Richardson, M. (1984, Autumn). The dictamen and its influence on fifteenth-century English prose. Rhetorica: A journal of the history of rhetoric, 2(3), 207-226. 
Richardson, M. (1985). Business writing and the spread of literacy in late medieval England. In G. Douglas \& H. Hildebrandt (Eds.), Studies in the history of business writing (pp. 19). Urbana, IL: Association for Business Communication.

Richardson, M. (1997). Women, commerce, and rhetoric in medieval England. In M. M. Wertheimer (Ed.), The rhetorical activities of historical women (pp. 133-149). Columbia, SC: University of South Carolina Press.

Rogers, P. (1989, Summer). Choice-based writing in managerial contexts: The case of the dealer contact report. The Journal of Business Communication 26(3), 197-216.

Stapleton, T. (1839). Plumpton correspondence. London: Camden Society.

Thomson, G. S. (1958). Wool merchants of the 15th century, London: Longman.

Thomas, J. (1994). The language of the Celys. (Doctoral dissertation, University of Michigan, 1994). University Microfilms International, 9423332.

Thrupp, S. L. (1992). The merchant class of medieval London. Ann Arbor: University of Michigan Press.

Yates, J., \& Orlikowski, W. J. (1995). Explicit and implicit structuring of genres: Electronic communication in a Japanese R\&D organization. Cambridge, MA: Alfred P. Sloan School of Management, Massachusetts Institute of Technology. Working paper Alfred P. Sloan School of Management WP \#3809-95.

Yates, J., \& Orlikowski, W. J. (1992). Genres of organizational communication: A structurational approach to studying communication and media. The Academy of Management Review, 172), 299-326. 